\title{
EFFECT OF BALL MILLING ON THE PROPERTIES OF THE POROUS Ti-26Nb ALLOY FOR BIOMEDICAL APPLICATIONS
}

\author{
VPLIV KROGLIČNEGA MLETJA NA LASTNOSTI POROZNE \\ ZLITINE Ti-26Nb ZA BIOMEDICINSKE APLIKACIJE
}

\author{
Grzegorz Dercz, Izabela Matuła \\ University of Silesia, Institute of Materials Science, 75 Pułku Piechoty Street 1 A, 41-500 Chorzów, Poland \\ grzegorz.dercz@us.edu.pl
}

Prejem rokopisa - received: 2016-09-09; sprejem za objavo - accepted for publication: 2017-02-21

doi:10.17222/mit.2016.269

\begin{abstract}
The current study investigated the effect of the ball-milling time on the structural characteristics and pore morphology of a biomedical porous $\mathrm{Ti}-26 \mathrm{Nb}(a / \%)$ alloy. An open-cell porous material was synthesized by mechanical alloying and sintering. Commercially available elemental metal powders of $\mathrm{Ti}$ and $\mathrm{Nb}$ were used as the starting materials. Elemental metal powders with a nominal composition of Ti-26Nb $(a / \%)$ were milled in a planetary ball mill. During the testing, the powders were milled for two milling times: $50 \mathrm{~h}$ and $70 \mathrm{~h}$. During the shorter milling time, the speed of $200 \mathrm{~min}^{-1}$ was applied, and during the longer milling time, the speed of $400 \mathrm{~min}^{-1}$ was applied. The powders were cold pressed under a pressure of $750 \mathrm{MPa}$ and then sintered at $1000{ }^{\circ} \mathrm{C}$ for $24 \mathrm{~h}$. The effects of the powder milling time on the microstructure and mechanical properties of the porous structure were investigated with optic microscopy (OM), scanning electron microscopy (SEM), X-ray diffraction (XRD), microhardness, nanoindentation and nanomachining tests. The hardness and elastic modulus were calculated from the load-displacement data obtained with nanoindentation using a three-sided, pyramidal, diamond (Berkovich) indenter tip. The $\mathrm{X}$-ray diffraction results confirmed the presence of the $\alpha$ and $\beta$ phases. An analysis of diffraction patterns revealed a decrease in the lattice parameters for the $70 \mathrm{~h}$ milling. In summary, it should be pointed out that the material has a hierarchical structure, obtained during the successive stages of milling. The observed grains are composed of many smaller grains, the size of which decreased with an increase in the milling time.

Keywords: mechanical alloying, porosity, nanoindentation, Ti-26Nb alloy
\end{abstract}

V študiji so preiskovali vpliv različno dolgega časa krogličnega mletja na strukturne značilnosti in morfologijo por biomedicinske porozne Ti-26Nb zlitine $(a / \%)$. Porozni material z odprtimi celicami je bil sintetiziran $\mathrm{z}$ mehanskim legiranjem in sintranjem. Osnovni metalurški prahovi z nominalno vsebnostjo Ti-26Nb $(a / \%)$ so bili mleti v planetarnem krogelnem mlinu. Med testiranjem so bili prahovi mleti pri dveh različnih časih: $50 \mathrm{~h}$ in $70 \mathrm{~h}$. Med krajšim časom mletja je bila uporabljena hitrost mletja $200 \mathrm{~min}^{-1}$ in med daljšim časom mletja je bila uporabljena hitrost $400 \mathrm{~min}^{-1}$. Prahovi so bili hladno stiskani pod tlakom $750 \mathrm{MPa}$ in nato sintrani pri $1000{ }^{\circ} \mathrm{C}$ za $24 \mathrm{~h}$. Preiskovali so vpliv različnega časa mletja prahu na mikrostrukturo in na mehanske lastnosti porozne strukture $\mathrm{z}$ optičnim mikroskopom, s SEM- in XRD-analizo ter določevanjem mikrotrdote in mehanske nanoobdelave. Trdoto in modul elastičnosti so izračunali iz meritev odvisnosti med obremenitvijo in globino vtisa tristranske diamantne konice (po Berkovichu). Rezultati rentgenske difrakcije so potrdili prisotnost $\alpha$ in $\beta$ faz. Skratka, poudariti je treba, da ima material hierarhično strukturo, ki je posledica faze mletja. Pregledana zrna so sestavljena iz mnogo manjših podzrn, katerih velikost se je zmanjševala s podaljševanjem časa mletja.

Ključne besede: mehansko legiranje, poroznost, nanovtiskovanje, zlitina Ti-26Nb

\section{INTRODUCTION}

Titanium-based alloys seem to be the preferred materials for orthopaedic applications. They are characterized by high biocompatibility, great corrosion resistance, light weight and good mechanical properties and have a relatively low modulus in comparison to the other materials used as implants. ${ }^{1}$ However, titanium-based alloys used for implants have important disadvantages. Firstly, popular alloying additives $(\mathrm{Al}, \mathrm{V})$ are dangerous for the health and life of a patient. ${ }^{2}$ Secondly, the metals used for implants have too high an elastic modulus in comparison to the mechanical properties of the bone. This difference between the mechanical properties induces stress between the implant and the bone. ${ }^{3}$ In recent years, due to intensive investigation, we have seen the production and development of various Ti-based alloys, among which there are Ti-Mo-based, Ti-Nb-based, Ti-Zr-based and Ti-Ta-based alloys. ${ }^{2}$

This work focuses on niobium as the additive to titanium because it has been recognized as an extremely promising element. $\mathrm{Nb}$ is highly biocompatible, has a low ionic in-vitro cytotoxicity, and most importantly there is no evidence of mutagenicity or carcinogenicity. ${ }^{4}$ The Ti-Nb-based alloys are attracting more researchers to study them due to their low modulus, good biocompatibility and shape-memory effect. Medical applications of SME (shape-memory effect) alloys will be especially increased in the near future, so the development and basic or extensive research of the Ti-based alloys are necessary. ${ }^{1,2,4,5}$ A series of studies confirmed the presence of the shape-memory effect and superelasticity in the alloys with the composition of Ti-26Nb $(a / \%)$ and also in approximate compositions of the elements. ${ }^{4-7}$ Most of 
these alloys are obtained with a conventional method such as arc melting. One of the alternatives to the widely used arc melting is powder metallurgy (PM). In the scientific literature, there are evidences of successful preparations of titanium-based materials with this production method..$^{8-10}$ This production method has a number of significant advantages. It allows creating alloys of materials with large differences between their melting temperatures or densities. The most important advantages of PM for the production of biomaterials are its low cost and the possibility to produce highly porous materials. ${ }^{4,11}$

The aim of the present paper is to determine the possibility to produce a $\mathrm{Ti}-26 \mathrm{Nb}(\mathrm{a} / \%)$ alloy using the powder-metallurgy method. Simultaneously, this research is to develop a technology of producing Ti-based alloys and estimate the influence of changing parameters during the mechanical alloying. Such research is the starting point for further development of nickel-free alloys with the shape-memory effect based on titanium and niobium. In this article, the influence of the milling time on the microstructure and mechanical properties of the produced alloy is investigated.

\section{EXPERIMENTAL PART}

Commercial elemental powders of $\mathrm{Ti}$ (Atlantic Equipment Engineers (AEE), $99.7 \%,<20 \mu \mathrm{m}$ ) and $\mathrm{Nb}$ (Atlantic Equipment Engineers (AEE), $99.8 \%,<5 \mu \mathrm{m}$ ) were used as the initial materials for the synthesis of the alloy. Elemental metal powders with the nominal composition of Ti-26Nb (a/\%) were milled for two different milling times, $50 \mathrm{~h}$ and $70 \mathrm{~h}$, in a planetary ball mill Fritch PULVERISETTE 7 premium line. To prevent the powder from oxidation as much as possible, the process was carried out in an argon-protective atmosphere. During the shorter milling time, the speed of $200 \mathrm{~min}^{-1}$ was applied, and for the longer milling time (with additional $20 \mathrm{~h}$ ), the speed of $400 \mathrm{~min}^{-1}$ was applied. The powders were cold isostatically pressed under a $750 \mathrm{MPa}$ pressure without any substances that improve the porosity (e.g., space holders). Then the material was sintered at $1000{ }^{\circ} \mathrm{C}$ for $24 \mathrm{~h}$ and cooled in the furnace to room temperature.

The crystalline structure and phase content of the sintered materials were tested with X-ray diffraction. The refinement of the X-ray diffraction pattern was carried out using Rietveld's whole X-ray profile fitting technique with the DBWS 9807a program. ${ }^{12}$ The profile function used to adjust the calculated diffractograms to the observed ones was the pseudo-Voigt one. ${ }^{13,14}$ The weight fraction of each component was determined based on the optimized scale factors with the use of the relation proposed by Hill and Howard. ${ }^{15,16}$ Based on the Williamson-Hall method, the crystallite sizes (D) and lattice strain $\langle\Delta a / a\rangle$ for the phases appearing in the material at various milling times were determined. The apparatus factors were eliminated using $\mathrm{LaB}_{6}$ (SRM 660a).

The morphology of the initial powders and the microstructure of the sintered material were tested using an optic microscope and scanning microscope JEOL JSM 6480 with an accelerating voltage of $20 \mathrm{kV}$. Additionally, a chemical analysis was performed using an EDS detector manufactured by IXRF using the standard calibration method.

An analysis of the microstructure was performed on microscopic images with the use of ImageJ, which is the software used for image processing and analysis. The size and shape of the grains were determined using the planimetric method. The study also included determining the inhomogeneity of the size of the grains. A quantitative analysis of the morphology of the material was performed using the stereological parameters presented below:

a) the size of the area of a section of grain $a\left(\mu \mathrm{m}^{2}\right)$,

b) dimensionless lengthening factor (Equation (1):

$$
f_{\mathrm{g} 1}=\frac{h}{w}
$$

where: $h$ - height and $w$ - width of the smallest rectangle described on the object,

c) dimensionless shape factor - the circularity:

$$
f_{\mathrm{g} 2}=\frac{4 \pi F}{L^{2}}
$$

where: $F$ - area of the analyzed object; $L$ - perimeter of the analyzed object,

d) grain-size change-ability factor:

$$
v=\frac{\sigma_{x}}{a}
$$

where: $\sigma_{x}$ - grain-size standard deviation; $a$ - grain mean value,

the number of analyzed elements per area unit of the image: $N_{A}\left[1 / \mathrm{mm}^{2}\right]$.

The thermal behavior of the martensitic transformation was studied using a differential scanning calorimeter (DSC) Mettler Toledo DSC-1. Transformation temperatures were determined from the thermograms measured at a heating rate of $10 \mathrm{deg} / \mathrm{min}$ and a thermal range of $-120{ }^{\circ} \mathrm{C}$ to $600{ }^{\circ} \mathrm{C}$.

The surface morphology, hardness and elastic modulus were tested using a Hysitron Triboindenter Ti950 with AFM QScope 250. The measurements were calculated from the load-displacement data obtained with the nanoindentation, using a three-sided, pyramidal, diamond (Berkovich) indenter tip. An area of $40 \mu \mathrm{m} \times$ $40 \mu \mathrm{m}$ was analyzed at a scanning frequency of $0.25 \mathrm{~Hz}$. The microhardness measurement was carried out parallel to the nanoindentation tests. The Vickers microhardness measurement was taken at a load of $500 \mathrm{~N}$ and a loading time of $10 \mathrm{~s}$ on a 401MVD microhardness tester. 
G. DERCZ, I. MATUŁA: EFFECT OF BALL MILLING ON THE PROPERTIES OF THE POROUS Ti-26Nb ...

\section{RESULTS AND DISCUSSION}

SEM micrographs of the initial metal powders are presented in Figure 1. The titanium-powder morphology is irregular, having sharp corners and rough surfaces. The dispersion of the $\mathrm{Ti}$ particles is wide and ranges from a few $\mu \mathrm{m}$ to even $50 \mu \mathrm{m}$. The niobium powder has a much wider dispersion of the particles in comparison to the Ti powder.

Some of the particles have the size below $10 \mu \mathrm{m}$, and the shape of these particles is irregular. Simultaneously, there are also very large particles, the sizes of which are greater even than $50 \mu \mathrm{m}$ and these particles have an irregular, polyhedral shape. As a result of the work-hardening effect and high density of defects such as dislocations and vacancies created during long ball-milling times, the fracture and welding of powders reach an equilibrium state. This state leads to the formation of rather equiaxed and small particles. ${ }^{16,17}$ However, due to the higher bonding strength of the finer particles, their ability to undergo further plastic deformation is decreased and a higher force is required to fracture the small particles during the ball-milling process. ${ }^{18}$ It is worth mentioning that the reduction in the particle size at a given milling time can also be influenced by the milling technique.

The morphologies of the $\mathrm{Ti}-26 \mathrm{Nb}(a / \%)$ powders at different milling stages are shown in Figure 2. The powder after the shortest milling time shows globular particles. In the picture with the higher magnification (Figure 2b), some cracks were observed, which is the beginning of the cyclic process of material milling during high-energy ball milling. In contrast, in the samples after $70 \mathrm{~h}$ of milling, the particles became larger and the shape of the particles became less globular. Moreover, the particles of this sample are cold welded and the powder particles, in particular, are composed of the welded layers of the material. This behavior of the material during the high-energy milling is consistent

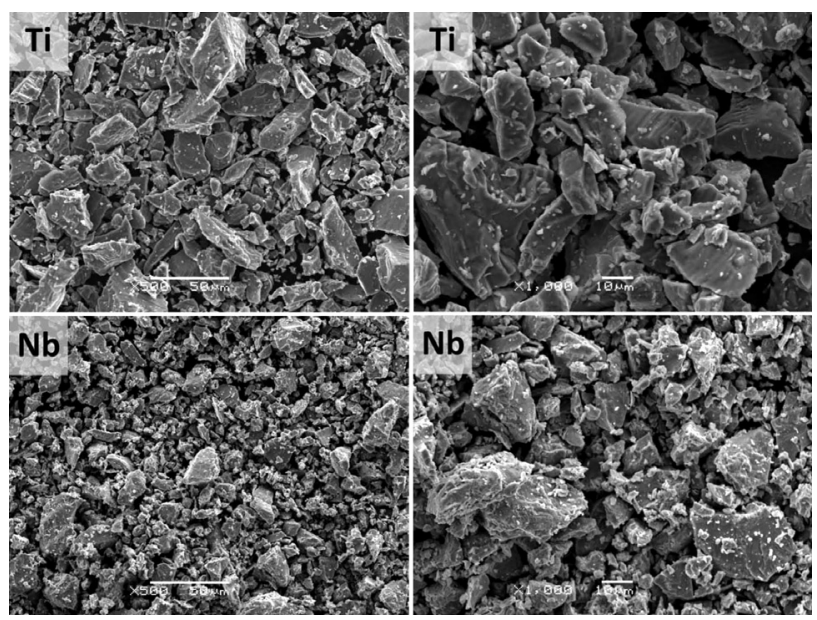

Figure 1: SEM micrographs of the initial $\mathrm{Ti}$ and $\mathrm{Nb}$ powders at different magnifications
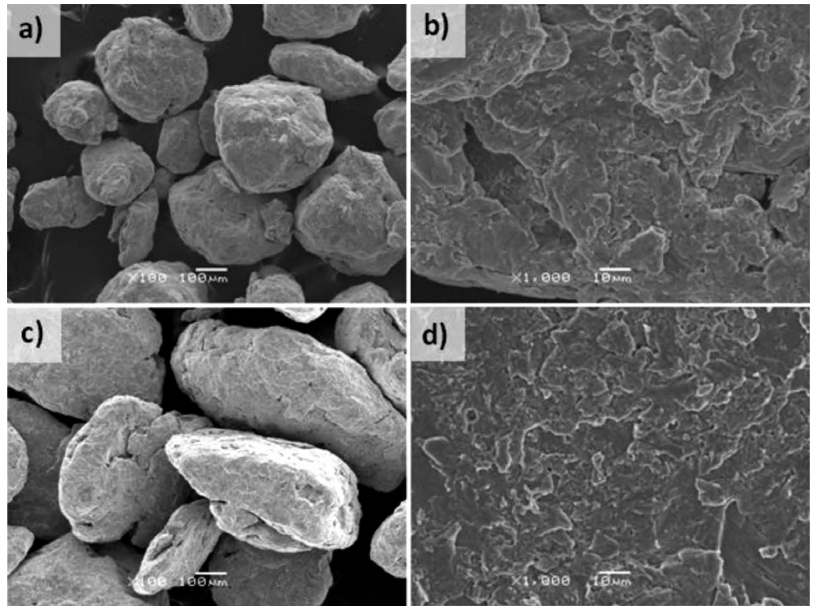

Figure 2: SEM micrographs of particles after different milling times: a), b) $50 \mathrm{~h}$ of milling and c), d) $70 \mathrm{~h}$

with the conduct and following steps of mechanical alloying. ${ }^{19}$ As shown by the other studies, the mechanical-alloying method leads to a decreased particle size, the $\beta$-Ti phase being stabilized by $\mathrm{Nb}$, and an increased surface area between $\mathrm{Ti}$ and $\mathrm{Nb}$. This promotes good homogeneity of the solid solution. ${ }^{20}$

Figure 3 shows a summary of diffraction patterns of the material after the mechanical synthesis, depending on the milling time of the initial powders. The X-ray qualitative analysis showed that only $\beta$ and $\alpha$ phases are present in the material after milling for $50 \mathrm{~h}$ and $70 \mathrm{~h}$. Change of the profile lines of individual diffraction patterns are clearly visible.

The broadening of the particle-size distribution at longer ball-milling times is a typical behavior of highenergy ball-milling process. ${ }^{17,19,21,22}$ For the $\beta$ and $\alpha$ phases, it was observed that a decrease in the crystallite size took place simultaneously with an increase in the milling time (Table 1). In addition, in the case of the $\beta$ phase there was a tendency towards a decrease in the lattice strain $<\Delta a / a\rangle$ (Table 1). The estimated size of the crystallites for the powder after milling for $70 \mathrm{~h}$ is $9(1)$ $\mathrm{nm}$ and 16(2) $\mathrm{nm}$ for the $\beta$ and $\alpha$ phases, respectively. The observed $\langle\Delta a / a\rangle$ lattice strain values indicate growth in the $\beta$ phase $(3.43 \mathrm{E}-03 \%)$ and in the $\alpha$ phase

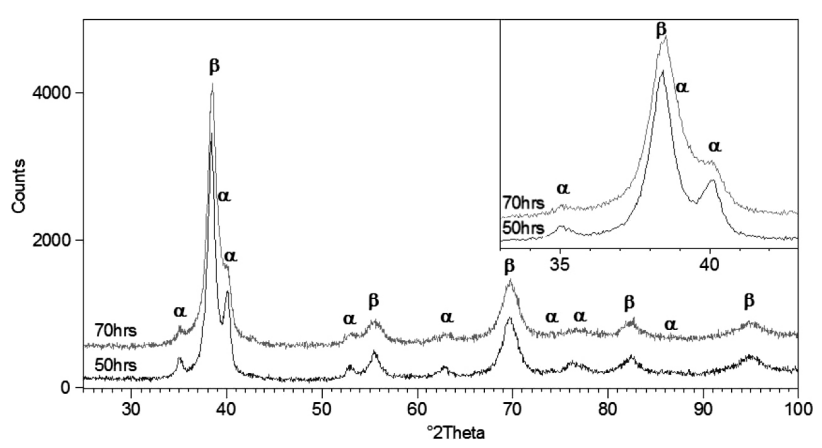

Figure 3: X-ray diffraction patterns of the powder after $50 \mathrm{~h}$ and $70 \mathrm{~h}$ of the milling process 
(2.31E-03\%). The analysis of the diffraction patters obtained using the Rietveld method showed that that high-energy milling has an influence on the lattice parameters.

Table 1: Changes of the average crystallite sizes (D) and lattice distortions $(<\Delta a / a\rangle)$ of the $\alpha$ and $\beta$ phases of the milled powders

\begin{tabular}{|c|c|c|c|c|}
\hline \multirow{2}{*}{ Phase } & \multicolumn{2}{|c|}{ Parameters } & \multicolumn{2}{c|}{ Milling time (h) } \\
\cline { 3 - 5 } & & 50 & 70 \\
\hline \multirow{2}{*}{$\alpha$} & $\mathrm{D}$ & $(\mathrm{nm})$ & $22(2)$ & $16(1)$ \\
\cline { 2 - 5 } & $<\Delta a / a>$ & $(\%)$ & $2.76 \mathrm{E}-03$ & $3.43 \mathrm{E}-03$ \\
\hline \multirow{2}{*}{$\beta$} & $\mathrm{D}$ & $(\mathrm{nm})$ & $15(2)$ & $9(1)$ \\
\cline { 2 - 5 } & $<\Delta a / a>$ & $(\%)$ & $2.04 \mathrm{E}-03$ & $2.31 \mathrm{E}-03$ \\
\hline
\end{tabular}

Table 2 presents lattice parameters determined for individual phases and the corresponding ICDD data sheets. In the case of the $\beta$ phase, a slight deviation of the $a_{0}$ lattice parameters from the catalogue data was observed. A similar type of cell contraction was discovered for the $a_{0}$ parameter of the $\alpha$ phase and for the $c_{0}$ parameter, but these changes are smaller, resulting from the shift systems for the phases of the hexagonal system. It should be stressed that for the sample after 70 $\mathrm{h}$ of milling, the deviation of both lattice parameters can be noted. It is probably the effect of the alternate cold welding and deposition of the particles during the mechanical synthesis.

Table 2: Lattice parameters and contents of $\alpha$ and $\beta$ phases of the milled powders

\begin{tabular}{|c|c|c|}
\hline \multirow{2}{*}{ Phase } & \multicolumn{2}{|c|}{ Lattice parameters $(\mathrm{nm})$} \\
\hline & & ICDD* \\
\hline \multirow{2}{*}{$\alpha$} & $a_{0}$ & 0.2970 \\
\hline & $c_{0}$ & 0.4720 \\
\hline$\beta$ & $a_{0}$ & 0.3307 \\
\hline
\end{tabular}

* International Centre for Diffraction Data ${ }^{\circledR}$ - a scientific organization dedicated to collecting, editing, publishing and distributing powderdiffraction data for the identification of materials

The quantitative phase analysis of the material after each stage show a successive progressive synthesis of the as-prepared powders in relation to the $\beta$ phase (77.5(11)) $\%$ mass fraction and 82.6(12) \% mass fraction, for $50 \mathrm{~h}$ and $70 \mathrm{~h}$ milling times, respectively).

The X-ray qualitative analysis showed that only $\beta$ and $\alpha$ phases are present in the samples annealed at $1000{ }^{\circ} \mathrm{C}$ for $24 \mathrm{~h}$ from the powder previously milled for $50 \mathrm{~h}$ and $70 \mathrm{~h}$, as shown in Figure 4. The XRD shows that there were no obvious diffraction peaks of elemental $\mathrm{Nb}$ remaining in the sintered $\mathrm{Ti}-26 \mathrm{Nb}(a / \%)$. The diffraction peaks attributable to the $\alpha$ and $\beta$ phases from the pattern confirm a duplex microstructure. M. Tahara et al. ${ }^{23}$ confirmed only the $\beta$ phase for $\mathrm{Ti}-26 \mathrm{Nb}(a / \%)$ produced by arc melting. The predominant phase in all the samples was the body-centered-cubic $(b c c) \beta$ phase. This indicates that $\mathrm{Nb}$ was diffused into Ti, thereby leading to the formation of $\alpha+\beta$ phases after the sintering.

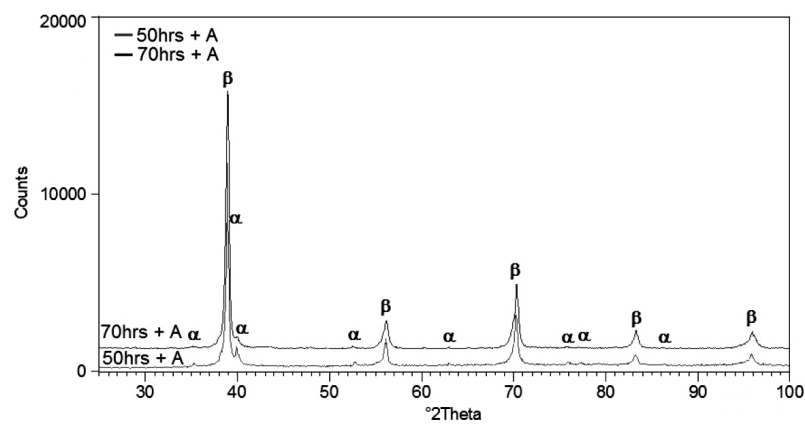

Figure 4: X-ray diffraction patterns for the samples annealed $(+\mathrm{A})$ at $1000{ }^{\circ} \mathrm{C}$ for $24 \mathrm{~h}$ from the powder previously milled for $50 \mathrm{~h}$ and $70 \mathrm{~h}$

This is significant because two-phase Ti alloys, with the major $\beta$ phase and the minor $\alpha$ phase, possess good comprehensive properties including high yield strength, excellent corrosion resistance and good fracture toughness.

The presence of unalloyed Ti particles in materials may arise from different facts. According to S. N. Patankar and F. H. Froes ${ }^{24}$, it could be correlated with the brittleness of the $\mathrm{Nb}$ particles, as compared to the $\mathrm{Ti}$ particles, since these brittle particles adhere to the surfaces of ductile particles. Another reason could be the limited solubility of $\mathrm{Nb}$ in $\alpha$-Ti. It is known that isomorphous $\beta$-stabilizer elements, such as $\mathrm{Nb}$, exhibit slower diffusivities in $\mathrm{Ti}$ than the eutectoid elements of $\mathrm{Fe}, \mathrm{Co}$ and $\mathrm{Ni}^{25}$

The structural analysis of the diffraction patters obtained using the Rietveld method showed that the lattice parameters for all the tested samples become reduced. In comparison to the ICDD data, it was found that high-energy milling and annealing have the smallest, but significant effect on the reduction of the size of a unit cell of the $\alpha$ and $\beta$ phases. The quantitative phase analysis (Table 3 ) of the material after annealing showed a significant synthesis of the as-prepared powders in relation to the $\beta$ phase 96.6(12) $w / \%$ and 98.8(12) $w / \%$ for samples previously milled for $50 \mathrm{~h}$ and $70 \mathrm{~h}$, respectively).

Table 3: Lattice parameters and contents of $\alpha$ and $\beta$ phases after annealing (A) the samples at $1000{ }^{\circ} \mathrm{C}$ for $24 \mathrm{~h}$ from the powder previously milled for $50 \mathrm{~h}$ and $70 \mathrm{~h}$

\begin{tabular}{|c|c|c|c|c|c|c|c|}
\hline \multirow{3}{*}{ Phase } & \multicolumn{4}{|c|}{ Lattice parameters (nm) } & \multirow{3}{*}{ Phase } & \multirow{2}{*}{\multicolumn{2}{|c|}{ Contents $(w / \%)$}} \\
\hline & & \multirow[b]{2}{*}{ ICDD* } & \multicolumn{2}{|c|}{ Rietveld } & & & \\
\hline & & & $\begin{array}{c}50 \mathrm{~h}+ \\
\mathrm{A}\end{array}$ & \begin{tabular}{|c}
$70 \mathrm{~h}+$ \\
$\mathrm{A}$
\end{tabular} & & $\begin{array}{c}50 \mathrm{~h}+ \\
\mathrm{A}\end{array}$ & $\begin{array}{c}70 \mathrm{~h}+ \\
\mathrm{A}\end{array}$ \\
\hline \multirow{2}{*}{$\alpha$} & $a_{0}$ & 0.2970 & $\begin{array}{c}0.2898 \\
(2)\end{array}$ & $\begin{array}{c}0.2891 \\
(2)\end{array}$ & $\alpha$ & $\begin{array}{l}3.4 \\
(6)\end{array}$ & $\begin{array}{l}1.2 \\
(4)\end{array}$ \\
\hline & $c_{0}$ & 0.4720 & $\begin{array}{c}0.4715 \\
(4)\end{array}$ & $\begin{array}{c}0.4710 \\
(4)\end{array}$ & \multirow{2}{*}{$\beta$} & \multirow{2}{*}{$\begin{array}{l}96.6 \\
(12)\end{array}$} & \multirow{2}{*}{$\begin{array}{l}98.8 \\
(12)\end{array}$} \\
\hline$\beta$ & $a_{0}$ & 0.3307 & $\begin{array}{c}0.3287 \\
(2)\end{array}$ & $\begin{array}{c}0.3286 \\
(2)\end{array}$ & & & \\
\hline
\end{tabular}

* International Centre for Diffraction Data ${ }^{\circledR}$ - a scientific organization dedicated to collecting, editing, publishing and distributing powder-diffraction data for the identification of materials

Optical and SEM micrographs of the studied samples are presented in Figures 5 and 6 . They clearly show the 
changes in the morphology of the material after sintering with respect to various milling times. The common feature of the samples is a hierarchical structure. After the milling, large-sized particles caused the formation of a porous material. The pores were large and interconnected (Figures 5a and 5c) in spite of the applied pressure of $750 \mathrm{MPa}$ during the isostatic pressing.

In the case of the sample milled for $50 \mathrm{~h}$ (Figure 5b), an anomalous grain growth was observed. SEM micrographs (Figure 6) revealed further differences between the obtained microstructures. The powders ball-milled for a long time cannot move and deform effectively during the compaction. This may be primarily due to the effects of the decrease in the particle size, solid-solution strengthening and work hardening of the particles during the ball-milling process. ${ }^{26,27}$ Amongst these factors, the work-hardening effect appears to be the main determinant in governing the plastic behavior of the powder particles during the compaction. In the ball-milling process, work hardening is caused by the interaction of
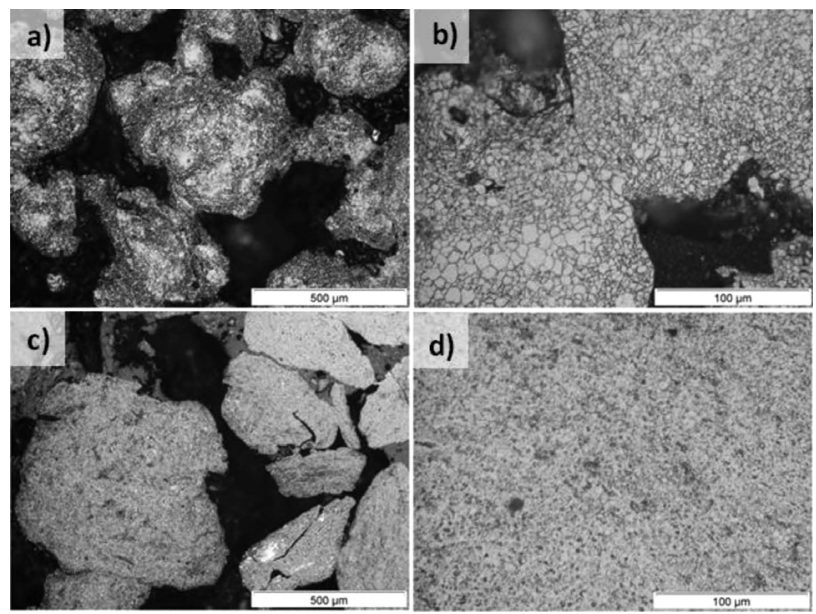

Figure 5: a), b) Optical micrographs of Ti-26Nb (a/\%) at different magnifications, produced in different milling times $-50 \mathrm{~h}$ and $\mathrm{c}$ ), d) $70 \mathrm{~h}$ and annealing
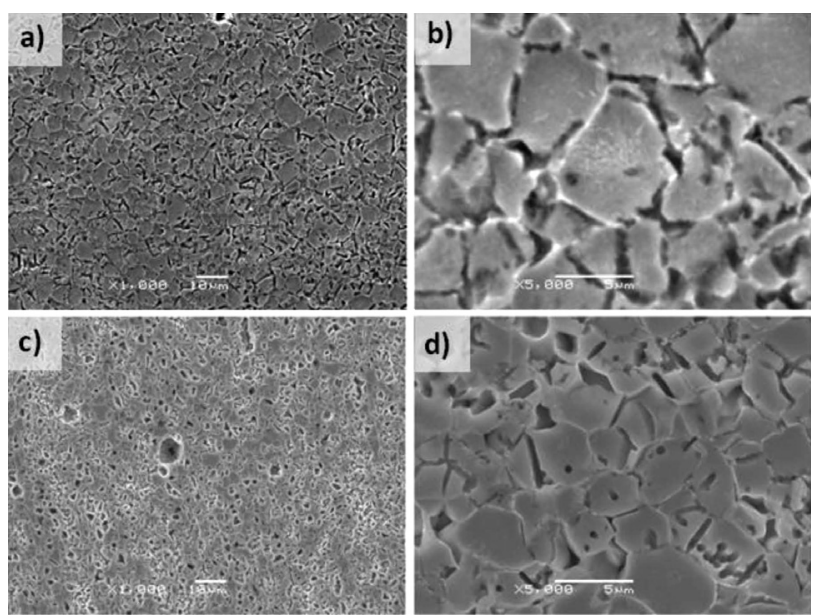

Figure 6: a), b) SEM micrographs of Ti-26Nb (a/\%) after different milling times $-50 \mathrm{~h}$ and c), d) $70 \mathrm{~h}$ and annealing dislocations with each other through the continuous mechanical impact of the balls on the powder particles. ${ }^{16}$

A quantitative analysis of the microstructure was conducted including the determination of the cross-sectional area of the grains and the subgrains, as well as the average circularity of the subgrains of the microsections based on microscopic images, the results of which are presented in Tables 4 to $\mathbf{6}$. Significant changes between the samples in the average $a$ of the grain cross-sectional area can also be observed. For the samples milled for $50 \mathrm{~h}$ and $70 \mathrm{~h}$, the average section area of grains was $9.09 \mu \mathrm{m}^{2}$ and $3.55 \mu \mathrm{m}^{2}$, respectively (Table 4). A change in the time and rotations per minute during milling causes a difference in the parameter.

Table 4: Results for the cross-sectional area of the grains for the samples milled for different times

\begin{tabular}{|c|c|c|c|c|c|}
\hline Parameter & Sample & $\begin{array}{c}\text { Minimum } \\
\text { value }\end{array}$ & $\begin{array}{c}\text { Maximum } \\
\text { value }\end{array}$ & $\begin{array}{c}\text { Average } \\
\text { value }\end{array}$ & Std. dev. \\
\hline \multirow{2}{*}{$a\left(\mu \mathrm{m}^{2}\right)$} & $50 \mathrm{~h}$ & 0.51 & 267.57 & 9.09 & 12.68 \\
\cline { 2 - 6 } & $70 \mathrm{~h}$ & 0.51 & 32.35 & 3.55 & 3.45 \\
\hline
\end{tabular}

Table 5: Results for the circularity of the grains for the samples milled for different times

\begin{tabular}{|c|c|c|c|c|c|}
\hline Parameter & Sample & $\begin{array}{c}\text { Minimum } \\
\text { value }\end{array}$ & $\begin{array}{c}\text { Maximum } \\
\text { value }\end{array}$ & $\begin{array}{c}\text { Average } \\
\text { value }\end{array}$ & Std. dev. \\
\hline \multirow{2}{*}{$f_{\mathrm{g} 2}$} & $50 \mathrm{~h}$ & 0.10 & 1.00 & 0.60 & 0.15 \\
\cline { 2 - 6 } & $70 \mathrm{~h}$ & 0.11 & 0.96 & 0.59 & 0.15 \\
\hline
\end{tabular}

Table 6: Results for the dimensionless lengthening factor of the grains for the samples milled for different times

\begin{tabular}{|c|c|c|c|c|c|}
\hline Parameter & Sample & $\begin{array}{c}\text { Minimum } \\
\text { value }\end{array}$ & $\begin{array}{c}\text { Maximum } \\
\text { value }\end{array}$ & $\begin{array}{c}\text { Average } \\
\text { value }\end{array}$ & Std. dev. \\
\hline \multirow{2}{*}{$f_{\mathrm{g} 1}$} & $50 \mathrm{~h}$ & 0.32 & 3.31 & 1.06 & 0.37 \\
\cline { 2 - 6 } & $70 \mathrm{~h}$ & 0.28 & 3.30 & 1.06 & 0.37 \\
\hline
\end{tabular}

Histograms of the size of the area of the section of the grains in the samples milled for $50 \mathrm{~h}$ and $70 \mathrm{~h}$ are presented in Figures $\mathbf{7}$ and 8, respectively. For the sample milled for $70 \mathrm{~h}$, a larger fraction of the grains with the section area in the range of $0.5-35 \mu \mathrm{m}$ can be observed. Milling for $70 \mathrm{~h}$ caused a significant fragmentation of the grains with the section area below $30 \mu \mathrm{m}^{2}$.

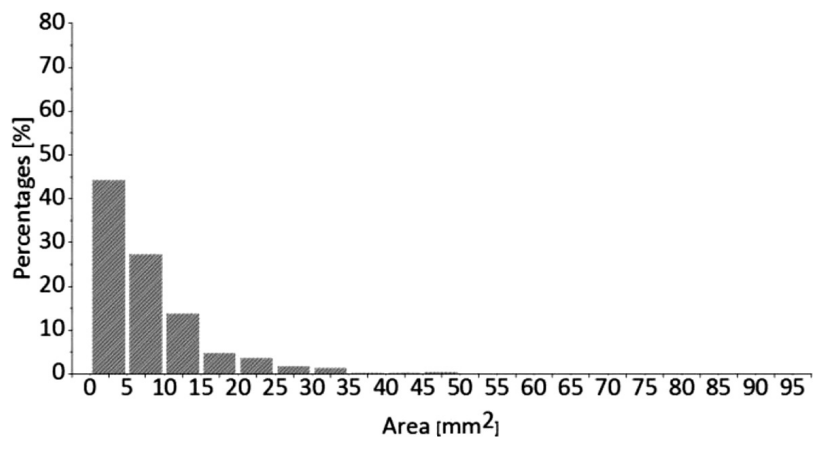

Figure 7: Histogram of the grain average area for the sample milled for $50 \mathrm{~h}$ and annealed 
G. DERCZ, I. MATUŁA: EFFECT OF BALL MILLING ON THE PROPERTIES OF THE POROUS Ti-26Nb ...

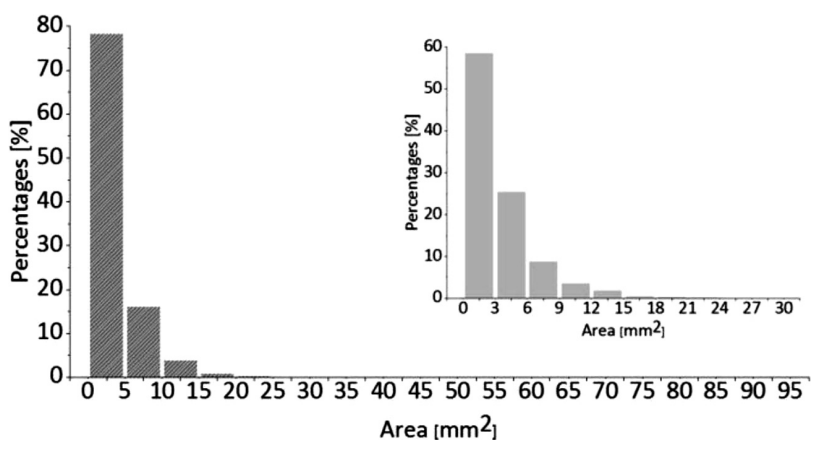

Figure 8: Histograms of the grain average area for the sample milled for $70 \mathrm{~h}$ and annealed. The upper histogram presents the distribution of the average area of the grains smaller than $36 \mu \mathrm{m}^{2}$ for this sample

The circularity of grains was 0.60 for $50 \mathrm{~h}$ of milling and 0.59 for $70 \mathrm{~h}$ of milling, which corresponds to the dimensionless lengthening factor for both samples (Tables 5 to 6). The coefficient of the grain variability was also determined. For all the samples milled for $50 \mathrm{~h}$, it was 1.4 , and for the sample milled for $70 \mathrm{~h}$, it was 0.9 . It means that for the sample milled for a shorter time, the size of the cross-sectional area is much more diversified in comparison to the sample milled for $70 \mathrm{~h}$. The longer milling time $(70 \mathrm{~h})$ caused a greater fragmentation of the material. The difference in the average section area of the grains was significant, especially when compared to the size of the powder after milling. No significant differences in the size of the particles depending on the milling time were noticed. The number of the elements that were tested per area unit of the image was also determined; for the samples annealed and previously milled for $50 \mathrm{~h}$ and $70 \mathrm{~h}$, the number of elements per area was estimated to be $82379\left[1 / \mathrm{mm}^{2}\right]$ and 199951 $\left[1 / \mathrm{mm}^{2}\right]$ respectively.

Distribution maps of the elements for the sintered samples revealed single regions rich in titanium in the case of the material milled for $50 \mathrm{~h}$ (Figure 9) Also, a slightly higher concentration of $\mathrm{Ti}$ was observed inside the grains. In contrast, milling for $70 \mathrm{~h}$ allowed us to obtain a material with an even distribution of the elements on its surface (Figure 10). In the case of this alloy, the increase in the milling time allows a more homogeneous structure.

Figures 11 and 12 show the effect of an analysis with the Hysitron Tribointender Ti950 with AFM QScope 250 , which allowed us to compare the surface topographies of the produced samples. For the material milled for $50 \mathrm{~h}$ and sintered, a higher diversification of the sample surface was observed. On the sample, initially synthetized for $70 \mathrm{~h}$ of milling, we can observe smaller and more regular grains in comparison to the sample exposed to the shorter milling time, which was confirmed with a stereological analysis.

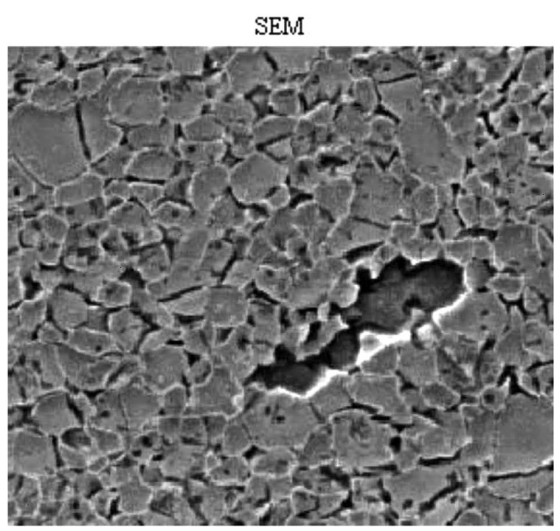

$\mathrm{Ti}$
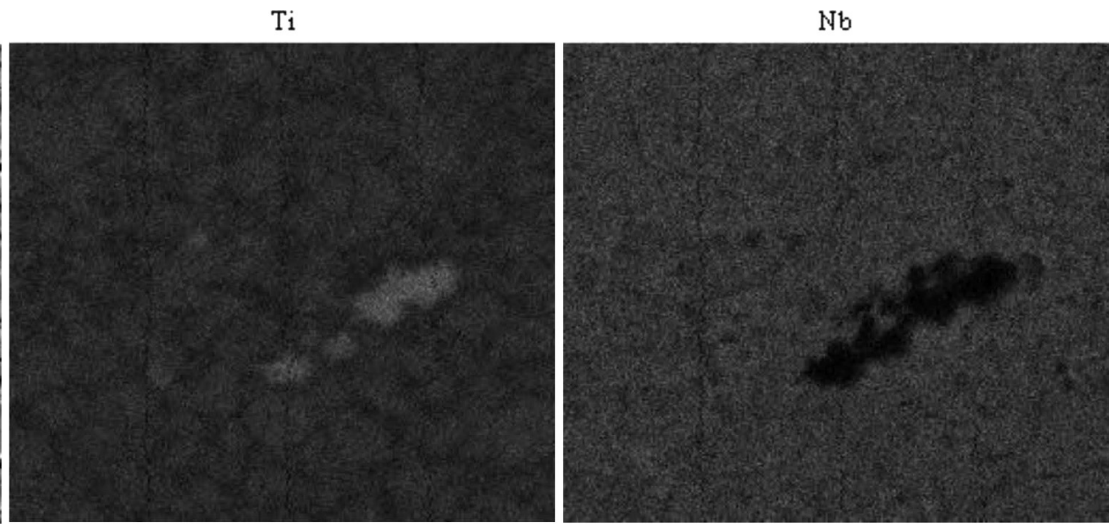

Figure 9: Distribution maps of the elements for the sample milled for $50 \mathrm{~h}$ and annealed

SEM

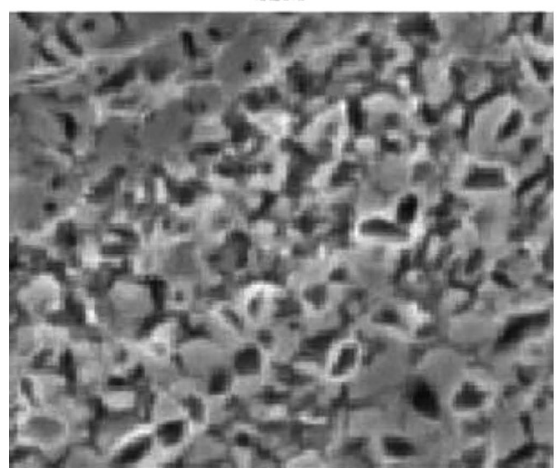

$\mathrm{Ti}$

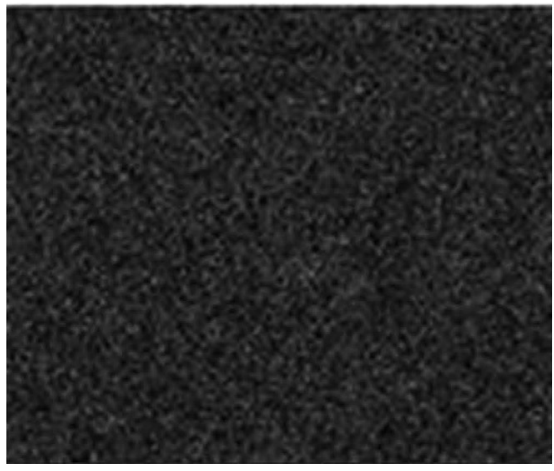

$\mathrm{Nb}$

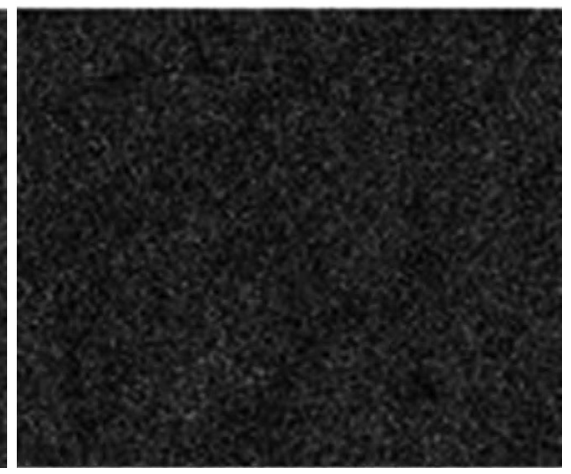

Figure 10: Distribution maps of the elements for the sample milled for $70 \mathrm{~h}$ and annealed 
G. DERCZ, I. MATUŁA: EFFECT OF BALL MILLING ON THE PROPERTIES OF THE POROUS Ti-26Nb ...

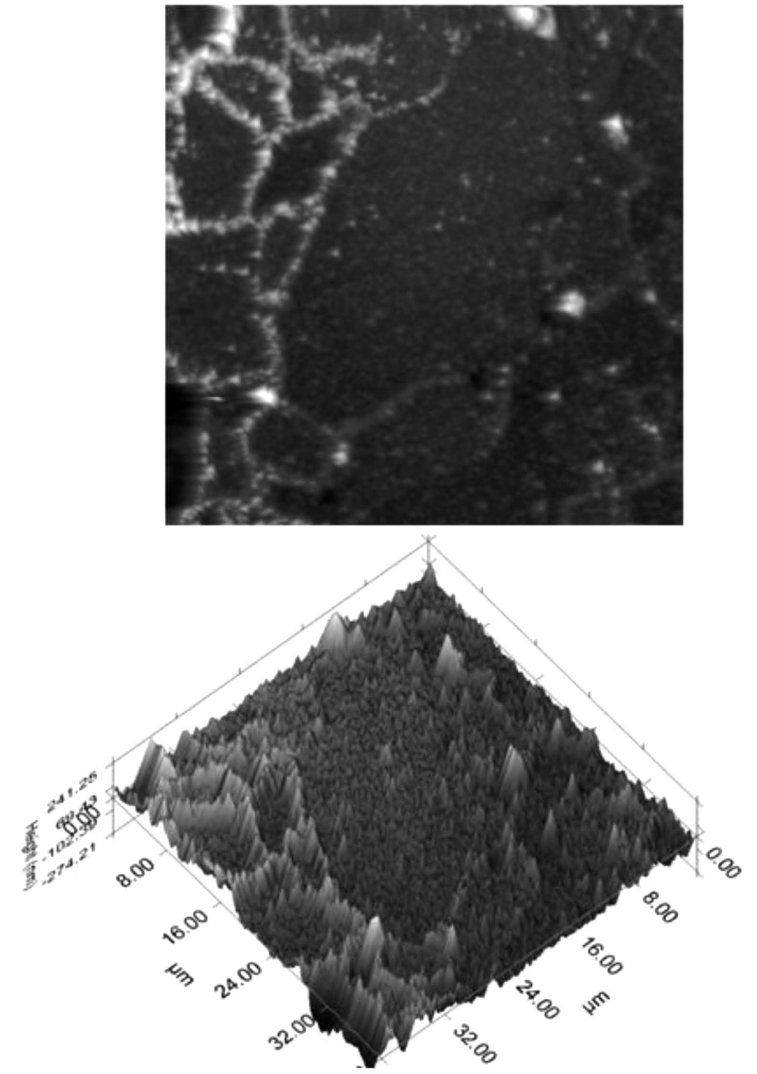

Figure 11: Surface morphology of the area of $40 \mu \mathrm{m} \times 40 \mu \mathrm{m}$ for the sample milled for $50 \mathrm{~h}$ and annealed

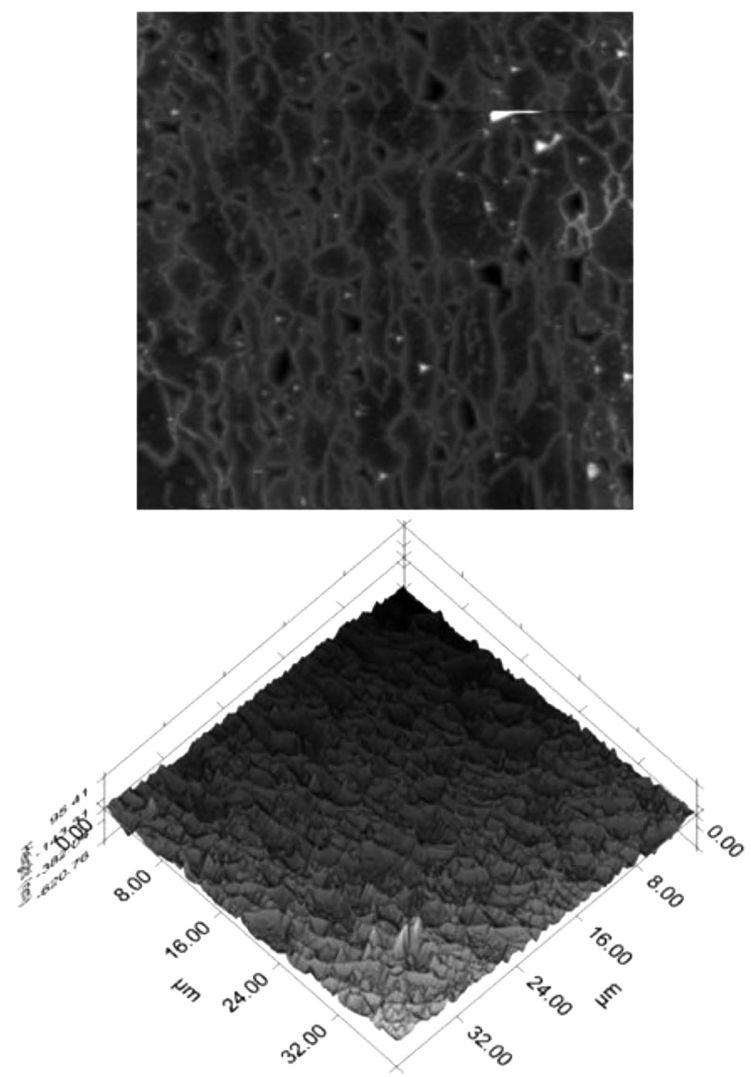

Figure 12: Surface morphology of the area of $40 \mu \mathrm{m} \times 40 \mu \mathrm{m}$ for the sample milled for $70 \mathrm{~h}$ and annealed

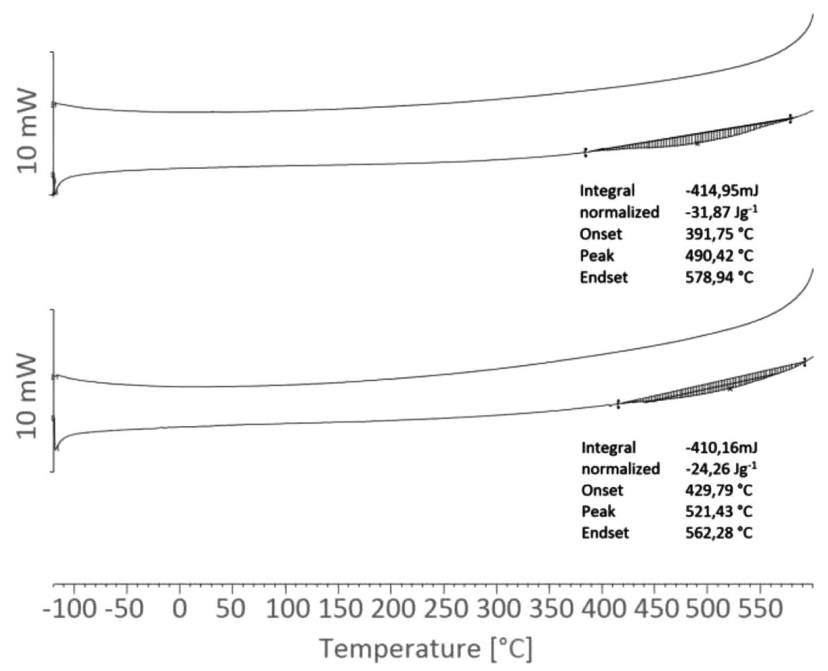

Figure 13: DSC analysis of the samples milled for $50 \mathrm{~h}$ and $70 \mathrm{~h}$ and also annealed

Another important aspect of the produced material is its properties. DSC results showed (Figure 13) the presence of an endothermic peak on the heating curve for both samples. In the case of the sample milled for $70 \mathrm{~h}$, the peak was slightly shifted toward higher temperatures. The peaks occurred at about $490{ }^{\circ} \mathrm{C}$ and $520^{\circ} \mathrm{C}$ for the samples milled for $50 \mathrm{~h}$ and $70 \mathrm{~h}$, respectively. The presence of the peaks can indicate the presence of a partial phase transformation $\alpha \rightarrow \beta$. Moreover, the milling time has an impact on the temperature of transformation. However, no significant changes were noticed on the cooling curves.

The nanoindentation method allowed the determination of the reduced Young's modulus and hardness of the material, and the results of this analysis of the material after different milling times and sintering are presented in Table 7.

Table 7: Results of the nanoindentation analysis - hardness and modulus of both samples

\begin{tabular}{|c|c|c|c|}
\hline Samples & $\begin{array}{c}\text { Contact depth } \\
(\mathrm{nm})\end{array}$ & $\begin{array}{c}\text { Hardness } \\
(\mathrm{GPa})\end{array}$ & Modulus (GPa) \\
\hline $50 \mathrm{~h}$ & $89(14)$ & $0.99(0.31)$ & $48(19)$ \\
\hline $70 \mathrm{~h}$ & $42(12)$ & $3.86(1.71)$ & $95(32)$ \\
\hline
\end{tabular}

The measurement is based on the curves of the load and the penetration depth of the indenter (Figures 14 and 15). After $50 \mathrm{~h}$ of milling, the material obtained much lower values of hardness and modulus in comparison to the material milled for $70 \mathrm{~h}$. For the samples milled for $50 \mathrm{~h}$ and $70 \mathrm{~h}$, the hardness was $0.99 \pm 0.31 \mathrm{GPa}$ and $3.86 \pm 1.71 \mathrm{GPa}$, respectively. A similar situation applied to the values of the modulus. For the material milled for $50 \mathrm{~h}$, it was $48 \pm 19 \mathrm{GPa}$, and for the material milled for $70 \mathrm{~h}$, it was $95 \pm 32 \mathrm{GPa}$. Such low modulus values, especially in the case of the sample with the shorter milling time, are very promising as they are close to the value of the modulus of a human bone. 
G. DERCZ, I. MATUŁA: EFFECT OF BALL MILLING ON THE PROPERTIES OF THE POROUS Ti-26Nb ...

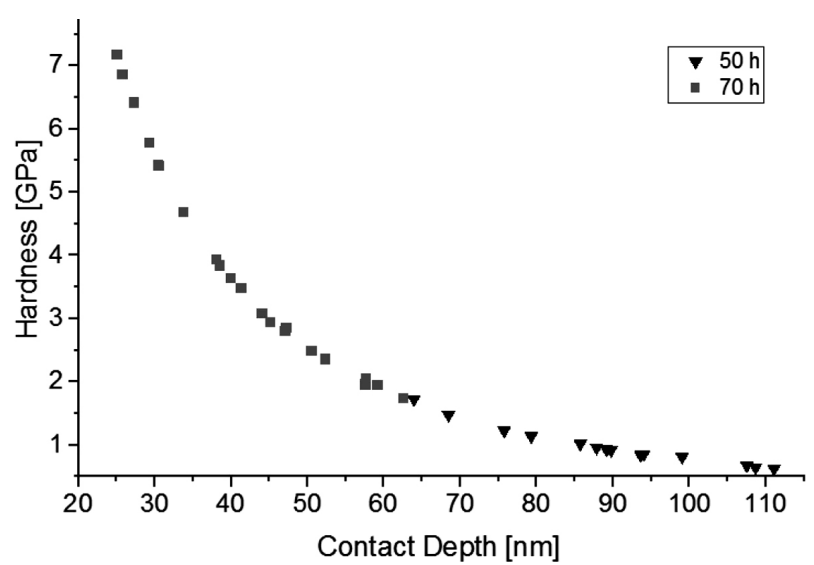

Figure 14: Diagram of hardness to contact depth for both samples, after $50 \mathrm{~h}$ and $70 \mathrm{~h}$ of milling

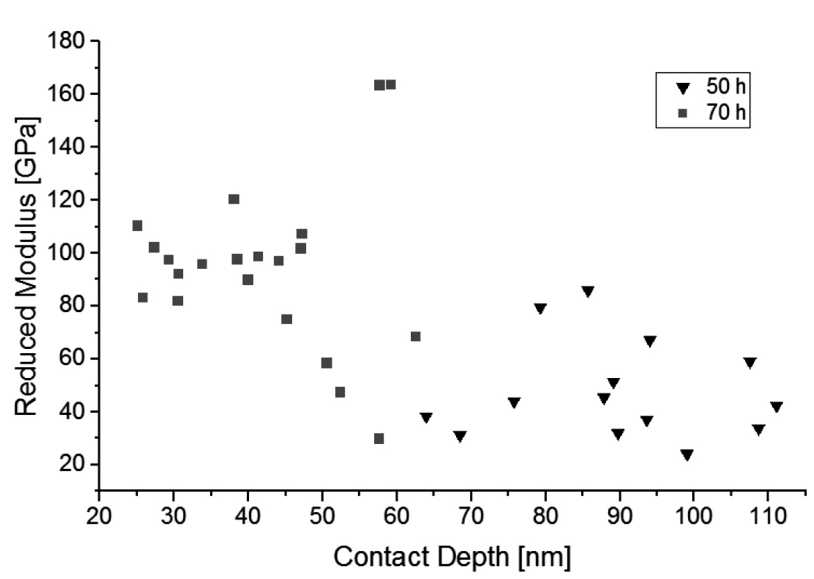

Figure 15: Diagram of reduced modulus to contact depth for both samples, after $50 \mathrm{~h}$ and $70 \mathrm{~h}$ of milling

The nanosized indentation measurements of the mechanical properties are from the selected specific areas, which neutralize the effects of the pores or defects on the results. A large measurement uncertainty is even more surprising. Assuming that the material is mechanically widely heterogeneous, it seems necessary to apply heat treatment to the material. The microhardness measurement of the sample milled for $50 \mathrm{~h}$ revealed a higher value of the microhardness and it is 288.6( \pm 31.0$)$ $\mathrm{HV} 0.5$, which is around $2.82 \mathrm{GPa}$. For the sample milled for $70 \mathrm{~h}$, the revealed value is $256.2( \pm 14.6) \mathrm{HV} 0.5$, which is approximately $2.51 \mathrm{GPa}$. However, we observed a relatively high uncertainty of the measurement, which made it difficult to clearly evaluate the differences in the microhardness measurement.

\section{CONCLUSIONS}

Based on the investigation into the microstructure and mechanical properties of the Ti-26Nb (a/\%) alloy, the main conclusions can be drawn:

- It was proved that the microstructure, the degree of porosity and mechanical properties can be adjusted by means of mechanical alloying.
- A longer milling time $(70 \mathrm{~h})$ resulted in an increased degree of structure fragmentation. Young's modulus increased twice as well.

- The porous samples sintered from the powders milled for 50 hours have a very low elastic modulus of 48(19) GPa, which is similar to that of natural bones.

- Ball-milling for $50 \mathrm{~h}$ led to the formation of a relatively equiaxed shape and powder particles of a smaller size and with a more asymmetrical particlesize distribution than that of the powders ball milled for $70 \mathrm{~h}$.

- Based on XRD, it was found that the process of high-energy milling for $50 \mathrm{~h}$ and $70 \mathrm{~h}$ makes it possible to obtain a solid nanocrystalline solution $\beta+\alpha$.

\section{Acknowledgments}

This work was supported by the Polish National Science Centre (Polish: Narodowe Centrum Nauki, abbr. NCN) under the research project no. UMO-2011/03/ D/ST8/04884

\section{REFERENCES}

${ }^{1}$ M. Long, H. J. Rack, Titanium alloys in total joint replacement - a materials science perspective, Biomaterials, 19 (1998) 18 , 1621-1639, doi:10.1016/S0142-9612(97)00146-4

${ }^{2}$ Y. Li, C. Yang, H. Zhao, S. Qu, X. Li, Y. Li, New Developments of Ti-Based Alloys for Biomedical Applications, Mater., 7 (2014) 3, 1709-1800, doi:10.3390/ma7031709

${ }^{3}$ M. Niinomi, Mechanical biocompatibilities of titanium alloys for biomedical application, J. Mech. Behav. Biomed. Mater., 1 (2008) 1, 30-42, doi:10.1016/j.jmbbm.2007.07.001

${ }^{4}$ A. Biesiekierski, J. Wang, M. Gepreel, C. Wena, A new look at biomedical Ti-based shape memory alloys, Acta Biomater. 8 (2012) 5, 1661-1669, doi:10.1016/j.actbio.2012.01.018

${ }^{5}$ S. Miyazaki, H.Y. Kim, Basic characteristics of titanium-nickel (Ti-Ni)-based and titanium-niobium (Ti-Nb)-based alloys, Shape Memory and Superelastic Alloys, Appl. Technol., (2011), 15-42, doi:10.1016/B978-1-84569-707-5.50002-X

${ }^{6}$ M. Tahara, H. Y. Kim, H. Hosoda, S. Miyazaki, Cyclic deformation behavior of Ti-26 at.\% Nb alloy, Acta Mater., 25 (2009), 2461-2469, doi:10.1016/j.actamat.2009.01.037

${ }^{7}$ H. Y. Kim, Y. Ikehara, J. I. Kim, H. Hosoda, S. Miyazaki, Martensitic transformation, shape memory effect and superelasticity of Ti-Nb binary alloys, Acta Mater. 54 (2006), 2419-2429, doi:10.1016/j.actamat.2006.01.019

${ }^{8}$ G. Dercz, I. Matuła, M. Zubko, A. Liberska, Structure characterization of biomedical Ti-Mo-Sn prepared by mechanical alloying method, Acta Phys. Pol. A, 130 (2016), 1029-1032, doi:10.12693/ APhysPolA.130.1029

${ }^{9}$ I. Matuła, G. Dercz, M. Zubko, L. Pająk, Influence of high energy milling time on the Ti-50Ta biomedical alloy structure, Acta Phys. Pol. A, 130 (2016), 1033-1036, doi:10.12693/APhysPolA.130.1033

${ }^{10}$ X. Rao, C. L. Chu, Y. Y. Zheng, Phase composition, microstructure, and mechanical properties of porous $\mathrm{Ti}-\mathrm{Nb}-\mathrm{Zr}$ alloys prepared by a two-step foaming powder metallurgy method, J. Mech. Behav. Biomed., 34 (2014), 27-36, doi:10.1016/j.jmbbm.2014.02.001

${ }^{11}$ G. Ryan, A. Pandit, D. P. Apatsidis, Fabrication methods of porous metals for use in orthopaedic applications, Biomaterials, 27 (2006) 13, 2651-2670, doi:10.1016/j.biomaterials.2005.12.002 


\section{MATERIALI IN TEHNOLOGIJE/MATERIALS AND TECHNOLOGY (1967-2017) - 50 LET/50 YEARS}

\section{G. DERCZ, I. MATUŁA: EFFECT OF BALL MILLING ON THE PROPERTIES OF THE POROUS Ti-26Nb ...}

${ }^{12}$ H. M. Rietveld, A Profile Refinement Method for Nuclear and Magnetic Structures, J. Appl. Cryst., 3 (1969), 65-69, doi:10.1107/ S0021889869006558

${ }^{13}$ R. J. Hill, C. J. Howard, Quantitative phase analysis from neutron powder diffraction data using the Rietveld method. J. Appl. Cryst., 20 (1987), 467-474, doi:10.1107/S0021889887086199

${ }^{14}$ G. Dercz, D. Oleszak, K. Prusik, L. Pająk, Rietveld-based quantitative analysis of multiphase powders with nanocrystalline $\mathrm{NiAl}$ and FeAl phases, Rev. Adv. Mater. Sci., 8 (2008), 764-768

${ }^{15}$ Y. Li, Y. Cui, F. Zhanga, H. Xua, Shape memory behavior in Ti-Zr alloys, Scripta Mater., 64 (2011) 6, 584-587, doi:/10.1016/ j.scriptamat.2010.11.048

${ }^{16}$ A. Nouri, P. D. Hodgson, C. Wen, Effect of ball-milling time on the structural characteristics of biomedical porous $\mathrm{Ti}-\mathrm{Sn}-\mathrm{Nb}$ alloy, Mater. Sci. Eng. C, 31 (2011), 921-928, doi:10.1016/j.msec.2011. 02.011

${ }^{17}$ G. Dercz, I. Matuła, M. Zubko, J. Dercz, Phase composition and microstructure of new Ti-Ta-Nb-Zr biomedical alloys prepared by mechanical alloying method, Powder Diffr., (2017), 1-7, doi:10.1017/S0885715617000045

${ }^{18}$ L. Lü, M. O. Lai, Mechanical Alloying, Kluwer Academic Publishers, Boston, 1998

${ }^{19}$ C. Suryanarayana, Mechanical alloying and milling, Prog. Mater. Sci., 46 (2001) 1-2, 1-184, doi:10.1016/S0079-6425(99)00010-9

${ }^{20}$ A. Omran, K. Woo, H. B. Lee, Mechanical properties of $\beta$-Ti$35 \mathrm{Nb}-2.5 \mathrm{Sn}$ alloy synthesized by mechanical alloying and pulsed current activated sintering, Metall. Mater. Trans. A, 43 (2012) 12, 4866-4874, doi:10.1007/s11661-012-1298-y
${ }^{21}$ G. Dercz, B. Formanek, K. Prusik, L. Pająk, Microstructure of $\mathrm{Ni}(\mathrm{Cr})-\mathrm{TiC}-\mathrm{Cr}_{3} \mathrm{C}_{2}-\mathrm{Cr}_{7} \mathrm{C}_{3}$ composite powder, J. Mater. Process. Tech., 162 (2005), 15-19, doi:10.1016/jmatprotec.2005.02.004

${ }^{22}$ G. Dercz, L. Pająk, B. Formanek, Dispersion analysis of NiAlTiC- $\mathrm{Al}_{2} \mathrm{O}_{3}$ composite powder ground in a high-energy attritorial mill, J. Mater. Process. Tech., 175 (2006), 334-337, doi:10.1016/ j.jmatprotec.2005.04.060

${ }^{23}$ M. Tahara, H. Y. Kim, H. Hosoda, S. Miyazaki, Cyclic deformation behavior of a Ti-26 at.\% Nb alloy, Acta Mater., 57 (2009), 2461-2469, doi:10.1016/j.actamat.2009.01.037

${ }^{24}$ E. K. Molchanova, Phase Diagrams of Titanium Alloys (Translation of Atlas Diagram Sostoyaniya Titanovyk Splavov), Israel Program for Scientific Translations, Jerusalem, 1965, 116

${ }^{25}$ S. N. Patankar, F. H. Froes, Transformation of mechanically alloyed $\mathrm{Nb}-\mathrm{Sn}$ powder to $\mathrm{Nb}_{3} \mathrm{Sn}$, Metall. Mater. Trans. A, 35 (2004), 3009-3012, doi:10.1007/s11661-004-0248-8

${ }^{26}$ P. J. James, Particle Deformation During Cold Isostatic Pressing of Metal Powders, Powder Metall., 20 (1977), 199-204, doi:10.1179/ pom.1977.20.4.199

${ }^{27}$ L. Lu, M. O. Lai, G. Li, Influence of sintering process on the mechanical property and microstructure of ball milled composite compacts, Mater. Res. Bull., 31 (1996), 453-464, doi:10.1016/S0025-5408(96) 00024-4 